\title{
KENDALA GURU DALAM PEMBELAJARAN TEMATIK JARAK JAUH SELAMA MASA PANDEMI COVID-19 DI MADRASAH IBTIDAIYAH NURUL UMMAH (MINU) KOTAGEDE YOGYAKARTA
}

\author{
Khanan Auladi, Argista Rahmaini, Mohammad Agung Rokhimawan \\ 19204080051@student.uin-suka.ac.id,19204080049@student.uin-suka.ac.id \\ rokhimawan78@gmail.com \\ UIN Sunan Kalijaga Yogyakarta
}

\begin{tabular}{c|c|c}
\hline \hline Received: & Revised: & Aproved: \\
30/06/2020 & $13 / 12 / 2020$ & $13 / 12 / 2020$ \\
\hline \hline
\end{tabular}

\begin{abstract}
This article aims to examine teacher constraints in distance thematic learning in a private school in Yogyakarta. The data in this study were obtained from observations, interviews, and documentation. The results of the study show that distance learning has components, functions, models and challenges in its application. Thematic distance learning in MINU serves as a substitute for conventional learning that has been carried out so far. The model used is Fully Online. In its implementation, the teacher experiences various obstacles both internal constraints of the educator himself and constraints outside the educator. The internal obstacle of educators is the lack of readiness of educators at the beginning of the implementation of distance thematic learning, because most have never attended distance learning training. While the obstacles outside the educator are related to substandard internet connections, mentoring of student guardians that are less than optimal, and students who are getting bored with distance learning. The contribution of this research to education in Indonesia is to illustrate the obstacles that will be faced by teachers in distance thematic learning. Distance learning training is immediately given to teachers so that distance learning can be done optimally.
\end{abstract}

Keywords: Covid-19, Education, Thematic.

\begin{abstract}
Abstrak
Artikel ini bertujuan untuk mengkaji kendala guru dalam pembelajaran tematik jarak jauh di sebuah sekolah swasta di Yogyakarta. Data dalam penelitian ini didapatkan dari observasi, wawancara, dan dokumentasi. Hasil dari penelitian menunjukan bahwa pembelajaran jarak jauh memikiki komponen, fungsi, model dan tantangan dalam penerapannya.
\end{abstract}


Pembelajaran tematik jarak jauh di MINU berfungsi sebagai pengganti pembelajaran konvensional yang selama ini dilaksanakan. Model yang dipakai berupa Fully Online. Dalam pelaksanaannya, guru mengalami berbagai kendala baik kendala di internal pendidik sendiri maupun kendala di luar pendidik. Kendala di internal pendidik yaitu ketidak siapan pendidik di awal penerapan pembelajaran tematik jarak jauh, karena sebagian besar belum pernah mengikuti pelatihan pembelajaran jarak jauh. Sementara kendala yang di luar pendidik yaitu terkait dengan koneksi internet yang kurang lancar, pendampingan wali murid yang kurang optimal, dan peserta didik yang mulai jenuh dengan pembelajaran jarak jauh. Adapun konstribusi penelitian ini terhadap pendidikan di Indonesia adalah memberi gambaran kendala-kendala yang akan dihadapi guru dalam pembelajaran tematik jarak jauh. Pelatihan pembelajaran jarak jauh sebaiknya segera diberikan kepada guru-guru agar pembelajaran jarak jauh dapat berjalan dengan optimal.

\section{Kata Kunci: Covid-19, Pendidikan, Tematik}

\section{A. Pendahuluan}

Pembelajaran jarak jauh bukanlah hal baru lagi di Indonesia, sejak Pemerintah menetapkan teknologi dalam pembelajaran. Upaya ini dilakukan agar tercapainya tujuan negara Indonesia yaitu mencerdaskan kehidupan bangsa. Luasnya negara Indonesia yang terbentuk dari beberapa pulau menjadi alasan yang kuat bagi negara untuk menerapkan pembelajaran jarak jauh. Pembelajaran jarak jauh sebagai suatu upaya interaksi pembelajaran dengan memanfaatkan fasilitas belajar berupa internet dan komputer.

Akibat penyebaran Coronavirus Disease (Covid-19) yang kian meluas akhirnya pemerintah memutuskan untuk mewajibkan semua kegiatan pembelajaran dilakukan dari rumah melalui pembelajara jarak jauh. Keputusan ini diambil karena mempertimbangkan kesehatan lahir dan batin peserta didik, pendidik, kepala sekolah dan seluruh warga sekolah adalah hal yang paling diutamakan. WHO (World Health Organization) mencatat bahwa pendemi ini telah menyebar ke 215 negara dengan 3.726.292 kasus yang telah tercatat serta telah menewaskan sedikitnya 257.405 jiwa. ${ }^{1}$

\footnotetext{
${ }^{1}$ World Health Organization (2020d) Rolling updates on coronavirus disease (COVID-19), Events as They Happen. Available at: https://www.who.int/emergencies/diseases/novel-
} 
Sementara di Indonesia sendiri telah tercatat 13.112 kasus positif dan sedikitnya telah menewaskan 943 jiwa. Sebagaimana telah diketahui virus ini dapat berpindah secara langsung melalui percikan batuk dan nafas orang yang telah terinfeksi yang kemudian terhirup oleh orang yang sehat. Selain pnyebarannya secara langsung, virus ini juga mampu menyebar dengan cara tidak langsung yaitu melalui benda-benda yang telah tercemar oleh virus ini akibat dari percikan batuk maupun bersin atau sentuhan tangan seseorang yang telah terinfeksi virus tersebut. ${ }^{2}$ Melihat penularannya yang terbilang sangat cepat dan mudah, maka pemerintah memutuskan untuk tidak menyelenggarakan pembelajaran dengan cara tatap muka. Sekolah-sekolah dan instansi pendidikan diliburkan dan sebagai penggantinya dilaksanakan pembelajaran jarak jauh sebagai upaya pemerintah untuk memutus mata rantai penularan virus ini.

Salah satu lembaga pendidikan yang terdampak dari adanya virus ini adalah SD/MI. Sebagaimana telah diketahui bahwa pembelajaran pada jenjang SD/MI menggunakan pembelajaran tematik. Pembelajaran tematik adalah suatu model pembelajaran terpadu yang didasarkan pada tema-tema tertentu yang disesuaikan dengan dunia anak. ${ }^{3}$ Dalam pembelajaran tematik pendidik dituntut agar mempunyai pengetahuan yang luas, kreatif, percaya diri, memiliki kemampuan metodologis yang baik, dan mampu mengemas dan mengembangkan materi. ${ }^{4}$ Ketrampilan-ketrampilan guru seperti ini juga seharusnya muncul dalam pembelajaran jarak jauh.

Pembelajaran jarak jauh ini kemungkinan besar akan berlangsung lama melihat prediksi yang digagas oleh Singapore University of Technology and Design (STUD) menyatakan bahwa pandemi covid-19 di Indonesia baru akan berakhir pada 7 Oktober 2020. Prediksi ini mundur dari prediksi mereka sebelumnya yang mengatakan pandemi covid-19 di Indonesia baru akan berakhir pada 6 Juni 2020. ${ }^{5}$

coronavirus-2019/events-as-they-happen (Accessed: 16 April 2020).

${ }^{2}$ Satgas Covid19, dalam https://covid19.go.id/berita/analisis-data-covid-19-indonesiaupdate-6-desember-2020 diakses 13 Desember 2020.

${ }^{3}$ Prastowo, Analisis Pemmbelajaran Tematik Terpadu, (Jakarta:Prenada Media, 2019), h.1.

${ }^{4}$ Prastowo, Analisis Pemmbelajaran Tematik Terpadu; ...h.13.

${ }^{5}$ Nafilah Sri Sagita K, "Prediksi Akhir Pandemi Corona di Indonesia Mundur Lagi Jadi Oktober.” dalam https://health.detik.com/berita-detikhealth/d-5011553/kembali-mundur-wabahcorona-di-indonesia-diprediksi-berakhir-28-oktober diakses 13 Desember 2020 
Bahkan menurut Center for Infectious Disease Research and Policy (CIDRAP) University of Minnesota pandemi ini baru akan benar-benar berakhir pada Januari 2020. ${ }^{6}$ Jika prediksi ini benar maka pembelajaran jarak jauh lebih lama dari apa yang diharapkan.

Melihat prediksi-prediksi akhir pandemic covid-19 yang masih lama seharusnya pendidik benar-benar siap dalam melakukan pembelajaran jarak jauh. Sehingga pembelajaran bisa berlangsung dengan baik meski dalam kondisi yang seperti ini. Seorang guru yang kreatif dan inovatif sangat dibutuhkan dalam pembelajaran jarak jauh ini sehingga peserta didik tidak pernah merasa jenuh dalam mengikuti pembelajaran.

Kebijakan untuk menggelar pembelajaran jarak jauh dalam keadaan terpaksa membuat sekolah-sekolah belum siap sepenuhnya. Terutama guru-guru belum mempersiapkan secara optimal segala sesuatunya terkait pembelajaran jarak jauh ini. Madrasah Ibtidaiyah Nurul Ummah (MINU) adalah salah satu lembaga pendidikan yang terdampak oleh pandemi covid-19 ini. Pembelajaran jarak jauh merupakan hal yang baru bagi MINU. Hal ini didasarkan pada hasil obsrvasi awal pada tanggal 23 Maret 2020 yang menunjukan bahwa guru-guru MINU baru mengenal beberapa media pembelajaran jarak jauh seperti Google Classroom dan Google Form.

Melihat pembelajaran jarak jauh yang masih merupakan hal baru di Madrasah Ibtidaiyah Nurul Ummah. Tentunya masih banyak kendala yang dihadapi khususnya guru dalam melaksanakan pembelajaran ini. Kendala-kendala ini harus segera diidentifikasi agar segera bisa ditemukan solusi yang tepat. Sehingga pembelajaran jarak jauh bisa berjalan dengan baik.

Numiek Sulistyo Hanum dalam penelitiannya menyatakan bahwa pelaksanaan pembelajaran e-learning di Sekolah Menengah Kejuruan Telkom Sandhy Putra Purwokerto tidak sepenuhnya efektif bagi semua guru di sana, ini dikarenakan adanya beberapa faktor dari pelaksanaannya yang belum optimal. ${ }^{7}$

${ }^{6}$ Osterholm dan Moore, “COVID-19: The CIDRAP Viewpoint.” dalam https://www.cidrap.umn.edu/covid-19/covid-19-cidrap-viewpoint diakses 13 Desember 2020

${ }^{7}$ Sulistyo Hanum, "Keefektifan E-Learning Sebagai Media Pembelajaran (Studi Evaluasi Model Pembelajaran E-Learning SMK Telkom Sandhy Putra Purwokerto).” dalam 
Sementara itu penelitian yang dilakukan oleh Euis Karwati menunjukkan bahwa pembelajaran elektronik berada dalam kategori yang tinggi, sementara kualitas pembelajaran berada dalam kategori cukup. Selain itu, diperoleh temuan bahwa pembelajaran elektronik memiliki pengaruh yang positif dan signifikan terhadap kualitas pembelajaran di FKIP UNINUS. ${ }^{8}$

Berdasarkan uraian di atas, penulis tertarik untuk melaksanakan Penelitian dengan judul “Kendala Guru dalam Pembelajaran Tematik Jarak Jauh Selama Masa Pandemi Covid-19 di Madrasah Ibtidaiyah Nurul Ummah (MINU) Kotagede Yogyakarta”. Penelitian ini memiliki tujuan agar dapat mengetahui kendala yang ditemui oleh guru dalam pelaksanaan pembelajaran tematik jarak jauh selama masa pandemi covid-19.

\section{B. Pembahasan}

\section{Kajian Teori}

Teori yang dipakai dalam artikel ini berhubungan dengan konsep dasar pembelajaran jarak jauh. Seperti penjelasan tentang apa itu pembelajaran jarak jauh dan apa saja komponen-komponennya, apa itu e-learning dan apa saja komponen-komponennya, fungsi e-learning dalam pembelajaran, model penyelenggaraan e-learning, posisi e-learning dalam pembelajaran jarak jauh, serta tantangan penerapan e-learning.

a. Pengertian Pembelajaran Jarak Jauh

Pendidikan jarak jauh adalah pendidikan dengan memanfaatkan berbagai sumber belajar melalui teknologi informasi dan komunikasi dan media lain dikarenakan antara pendidik dan peserta didiknya terpisah satu sama lain. ${ }^{9}$

Pembelajaran jarak jauh awalnya dilakukan dengan mengirim pendidik ke luar kampus agar peserta didik dapat menerima pengajaran

https://eprints.uny.ac.id/10946/ diakses 13 Desember 2020

${ }^{8}$ Karwati, "Pengaruh Pembelajaran Elektronik (E-Learning) Terhadap Mutu Belajar Mahasiswa."

dalam

https://www.researchgate.net/publication/296686483_Pengaruh_Pembelajaran_Elektronik_E-

Learning_terhadap_Mutu_Belajar_Mahasiswa diakses 13 Desember 2020

${ }^{9}$ UU Nomor 20 Tahun 2003 Pasal 1Ayat 15. 
secara tatap muka dari pendidiknya. Hal ini dikarenakan pada saat itu masih belum banyak terdapat bangunan persekolahan yang merata di berbagai tempat. Seiring dengan perkembangan teknologi pendidikan yang kian maju akhirnya pengertian pembelajaran jarak jauh seperti ini sudah tidak dipakai lagi. Pemahaman baru mengarah pada pembelajaran yang dilaksanakan tanpa bertatap muka antara pendidik dan peserta didik dengan melalui perantara teknologi telekomunikasi interaktif. Titik pijak karakteristik pendidikan jarak jauh adalah adanya keterpisahan antara pendidik dan peserta didik secara fisik. ${ }^{10}$

Simonson, Smaldino, Albright dan Zvacek dalam Dewi Salma dkk. menjelaskan bahwa pendidikan jarak jauh adalah pendidikaan formal berbasis lembaga, di mana kelompok belajarnya terpisah satu sama lain, dengan memanfaatkan sistem telekomunikasi sebagai sarana untuk menghubungkan antara peserta didik, sumber belajar, dan pendidik.

Sementara itu Hillary Perraton seperti dikutip oleh Dewi Salma dkk. menjelaskan bahwa pembelajaran jarak jauh adalah proses pengajaran di mana mayoritas bagian pembelajarannya dilakukan oleh pendidik yang terpisah dengan peserta didiknya.

Departemen Pendidikan Amerika Serikat dalam Dewi Salma dkk. mendefinisikan pembelajaran jarak jauh sebagai suatu pembelajaran dengan menerapkan teknologi telekomunikasi dan segala bentuk peralatan elektronik sehingga dimungkinkan siswa dapat menerima pembelajaran dari pendidiknya meskipun tidak saling bertatap muka. ${ }^{11}$

Definisi-definisi yang telah disebutkan di atas menunjukan pembelajaran jarak jauh mempunyai karakteristik yaitu dipakainya teknologi telekomunikasi sebagai sarana yang mempertemukan antara pendidik dan peserta didik. Internet menjadi salah satu media terbaru yang dimanfaatkan dalam pembelajaran jarak jauh.

\footnotetext{
${ }^{10}$ Darmawan, Pengembangan E-learning Teori dan Desain, (Bandung: Remaja Rosdakarya, 2014) h. 42.

${ }^{11}$ Salma dan dkk., Mozaik Teknologi Pendidikan: E-learning, (Jakarta: Prenada Media, 2013) h.28-29.
} 
Selanjutnya pembelajaran jarak jauh dengan memanfaatkan sarana internet ini lebih dikenal dengan electronic learning (e-Learning). Karta Sasmita sebagaimana dikutip oleh Darmawan menjelaskan bahwa $e$ Learning merupakan suatu bentuk khusus dari pembelajaran jarak jauh. ${ }^{12}$ b. Komponen Pembelajaran Jarak Jauh ${ }^{13}$

Pembelajara jarak jauh memiliki banyak komponen diantaranya yaitu peserta didik, pengajar, bahan ajar, proses belajar, dan lembaga yang menyelenggarakan pembelajaran jarak jauh. Komponen pembelajaran jarak jauh secara lebih operasional dapat diringkas menjadi empat komponen.

Komponen pertama adalah lembaga penyelenggara. Lembaga penyelenggara merupakan konsep utama pembelajaran jarak jauh, komponen ini sekaligus menjadi pembeda dengan belajar sendiri atau autodidak. Lembaga penyelenggara ini dapat berupa penyelenggara pendidikan konvensional seperti universitas, sekolah, akademi dan lain-lain. Atau berupa lembaga penyelenggara yang khusus menyelenggarakan pembelajaran jarak jauh.

Komponen kedua adalah adanya keterpisahan secara fisik antara pendidik dan peserta didiknya. Pendidik dengan peserta didik terpisah secara lokasi maupun waktu. Artinya, pembelajaran yang disampaikan oleh pendidik kepada peserta didiknya dipisahkan oleh jarak dan waktu.

Komponen ketiga adalah menggunakan suatu sistem telekomunikasi interaktif. Keterpisahan secara fisik antara pendidik dan peserta didik membutuhkan sesuatu yang dapat menghubungkan keduanya sehingga nantinya dimungkinkan akan terjadi komunikasi jarak jauh. Sistem telekomunikasi interaktif memiliki peran yang sangat penting dalam hal ini. Selain itu terjadinya interaksi antara pendidik dan peserta didiknya merupakan kunci dari suatu proses pembelajaran.

Komponen keempat adalah adanya saling berbagi data, suara maupun video yang diharapkan akan memberikan pengalaman belajar. Artinya, objek

\footnotetext{
${ }^{12}$ Darmawan, Pengembangan E-learning Teori dan Desain, ...h.43.

${ }^{13}$ Salma dan dkk., Mozaik Teknologi Pendidikan: E-learning,..h.29-32.
} 
belajar sebagai media pembelajaran dapat berupa data, suara, video, maupun multimedia. Tujuan dari kegiatan ini adalah agar peserta didik dapat memperoleh pengalaman belajar yang sesuai dengan kebutuhan dan karakteristik peserta didik agar selaras dengan tujuan pembelajaran serta sebagai bentuk penyediaan sarana dan prasarana pendukungnya.

c. Pengertian E-Learning

Kata e-Learning merupakan akronim dari “electronic learning” yang dapat diartikan sebagai suatu pembelajaran yang memanfaatkan bantuan peragkat elektronika, khususnya komputer. Sukarwati, Haryono, dan Librero segabaimana dikutip oleh Darmawan menjelaskan bahwa pembelajaran online atau sering disebut dengan e-Learning adalah pelaksanaan pembelajaran yang didukung dengan jasa elektronis seperti telepon, audio, videotape, tranmisi satelit atau komputer. ${ }^{14}$ Secara lebih sederhana $e$ Learning dapat disebut sebagai suatu pembelajaran yang diberdayakan oleh teknologi elektronik. ${ }^{15}$

E-Learning merupakan hasil kombinasi antara informasi, interaksi, dan komunikasi pendidikan yang merupakan bagian yang sangat penting agar tercapainya keberhasilan pebelajaran. Dalam e-Learning peserta didik untuk dapat mempelajari materi yang telah diberikan oleh pendidik kepada mereka tidak harus selalu dilakukan di dalam karena pendidik dapat memberikan materi pembelajarannya dengan cara memanfaatkan sarana internet sehingga peserta didik dapat mengaksesnya kapan pun dan di mana pun saat diperlukan. ${ }^{16}$

E-Learning merupakan suatu pembelajaran yang memanfaatkan kecanggihan fasilitas TIK yang dapat memberikan kemudahan bagi penggunanya untuk belajar secara mandiri, kapan pun dan di mana pun, sehingga menjadikan mereka senang akan belajar dan terus berupaya dalam meningkatkan kompetensi belajarnya. Adanya dorongan semacam ini

\footnotetext{
${ }^{14}$ Darmawan, Pengembangan E-learning Teori dan Desain, ...h45.

${ }^{15}$ Salma dan dkk., Mozaik Teknologi Pendidikan: E-learning, ...h.34.

${ }^{16}$ Darmawan, Pengembangan E-learning Teori dan Desain, ...h.49.
} 
menunjukkan bahwa dalam diri pembelajar terdapat motivasi yang tinggi untuk mempelajari materi-materi pembelajaran di dalam e-Learning. ${ }^{17}$

d. Karakteristik E-Learning

Pertama, pemanfaatan teknologi elektronik; dimana pendidik dan peserta didik, peserta didik dan sesamanya atau pendidik dan sesamanya dapat berkomunikasi dengan cara yang relatif mudah tanpa harus dibatasi dengan hal-hal yang bersifat protokoler. Kedua, pemanfaatan keunggulan komputer yang berupa media digital dan jaringan komputer. Ketiga, penggunaan bahan ajar bersifat mandiri yang disimpan di dalam komputer sehingga nantinya dapat diakses baik oleh pendidik maupun peserta didik di mana pun mereka berada dan kapan pun mereka memerlukannya. Keempat, pemanfaatan jadwal pembelajaran, kurikulum, hasil perkembangan belajar peserta didik dan semua hal yang berhubungan erat dengan administrasi pendidikan dapat dilihat kapan pun di komputer. ${ }^{18}$

e. Komponen E-Learning ${ }^{19}$

Sama halnya dengan pembelajaran jarak jauh, e-Learning juga memiliki beberapa komponen. Menurut Badrul Khan dalam Dewi Salma $e$ Learning setidaknya memiliki sembilan komponen.

Komponen pertama yaitu lembaga penyelenggara. Artinya, adanya pengelola yang bertugas untuk meangani permasalahan akademik, kesiswaan, yang dimulai dari perencanaan, penganggaran, implementasi, evaluasi, monitoring, dan lain-lain.

Komponen kedua adalah sistem pengelolaan. Artinya, sistem pengelolaan yang dapat mengelola lingkungan pembelajaran dan distribusi informasi.

Komponen ketiga yaitu sistem pembelajaran. Artinya, adanya sebuah sistem proses belajar dan mengajar yang didalamnya mencakup apa yang

17 Pusvyta Sari. 2015. Memotivasi Belajar dengan Menggunakan E-Learning. Jurnal Ummul Qura. Vol. 6. No. 2. Hlm. 25.

${ }^{18}$ Mohammad Yazdi. 2012. E-learning sebagai Media Pembelajaran Interaktif Berbasis Teknologi Informasi. Jurnal Ilmiah Foristek. Vol. 2. No. 1. Hlm. 147.

${ }^{19}$ Salma dan dkk., Mozaik Teknologi Pendidikan: E-learning, ...h.34-36. 
akan dipelajari, tujuan pembelajaran, siapa yang belajar, strategi pembelajaran, dan evaluasi dari hasil belajar.

Komponen keempat adalah teknologi yang digunakan. Artinya, teknologi apa saja yang dibutuhkan dalam pelaksanaan pembelajaran $e$ Learning yang di dalamnya meliputi perencanaan dan penyiapan infrastruktur yang diperlukan, baik hardware maupun software.

Komponen kelima yaitu sistem evaluasi. Hal ini meliputi evaluasi hasil pembelajaran maupun evaluasi program penyelenggaraan e-Learning secara menyeluruh.

Komponen keenam adalah tampilan e-Learning. Hal ini meliputi desain antar muka yang meliputi tampilan halaman situs, navigasi, konten, kemudahan penggunaan, interaktivitas, kecepatan muat dan lain-lain.

Komponen ketujuh yaitu layanan bantuan belajar. Hal ini terkait bagaimana peserta didik bisa mendapatkan layanan bantuan dengan segera.

Komponen kedelapan adalah masalah etika. Artinya, aturan-aturan yang dipakai dalam pembelajaran e-Learning.

Menurut Gottschalk, komponen-komponen pokok dalam pembelajaran e-learning yaitu terdiri dari:

1) Pelajar, pembelajaran e-learning yang efektif ciri dasarnya adalah terpenuhinya semua kebutuhan pelajar yang mendukung kegiatan ini. Tantangan-tantangan baru akan muncul seiring dengan penyampaian instruksi melalui jarak jauh, hal ini disebabkan karena pelajar satu dengan lainnya terpisahkan oleh jarak dan waktu bahkan mereka juga memiliki perbedaan latar belakang.

2) Fakultas, keberhasilang e-learning tergantung pada fakultas. Peranperan yang harus dimiliki instruktur dalam pembelajaran e-learning adalah:

(a) Mampu memahami karaktersitik masing-masing pelajar dan mengetahui kebutuhan-kebutuhannya dengan tanpa melakukan kontak langsung dengan mereka,

(b) Mampu menerapkan metode-metode pembelajaran yang sejalan 
dengan tujuan belajar,

(c) Senantiasa mengembangkan teknologi-teknologi penyampaian, dengan tetap berfokus pada peran yang dimilikinya yaitu sebagai seorang pengajar, dan

(d) Menjadi fasilitator yang mahir agar dapat berfungsi dengan efektif.

3) Fasilitator, tugas seorang fasilitator adalah mengikuti semua arahan yang diberikan oleh pengajar kepadanya. Fasilitator memiliki tugas untuk menyediakan peralatan-peralatan yang dibutuhkan, mengumpulkan tugas, mengawasi jalannya ujian, dan menjadi indera bagi instruktur.

4) Staf Pendukung, staf pendukung memiliki tugas untuk memastikan detail-detail yang dibutuhkan terkait dengan keberhasilan program $e$ learning yang sedang berlangsung. Kebanyakan keberhasilan program e-learning memiliki staf pendukung yang mampu mengurus dengan baik pendaftaran belajar, menduplikasi serta mendistribusikan materi, melakukan pemesanan buku pelajaran, membuat jadwal fasilitas, memroses nilai, dan lainnya.

5) Administrator, fungsinya adalah sebagai penengah, pembuat keputusan dan kesepakatan. Tugas mereka adalah memastikan seluruh sumber daya teknologi yang digunakan berjalan dengan efektif agar misi akademik lembaga dapat terus berjalan serta senantiasa mempertahankan fokus akademik agar selalu berada di jalur yang benar. ${ }^{20}$

f. Fungsi E-Learning Dalam Kegiatan Pembelajaran ${ }^{21}$

Menurut Siahaan sebagaimana dikutip oleh Darmawan E-Learning dalam kegiatan pembelajan memiliki tiga fungsi yaitu sebagai suplemen (tambahan), komplemen (pelengkap), dan substitusi (pengganti).

E-Learning memiliki fungsi sebagai tambahan artinya, peserta didik diberi kebebasan untuk memilih apakah mereka akan menggunakan materi

${ }^{20}$ Intan Mutia, Leonard. 2013. Kajian Penerapan E-Learning dalam Proses Pembelajaran di Perguruan Tinggi. Faktor Exacta. Vol. 6. No. 4. Hlm. 281.

${ }^{21}$ Darmawan, Pengembangan E-learning Teori dan Desain, ...h.50-53. 
e-learning atau tidak. Peserta didik tidak diberi kewajiban untuk mengakses materi e-learning. Namun, jika peserta didik memanfaatkannya maka tentu akan mendapatkan tambahan pengetahuan.

E-Learning memiliki fungsi sebagai komplemen (pelengkap) artinya, materi yang diprogramkan memiliki tujuan sebagai pelengkap bagi materi pembelajaran yang telah diperoleh peserta didik di dalam kelas. Dalam hal ini materi yang diprogramkan bisa berupa materi penguatan atau materi remidial. Dikatakan sebagai penguatan jika tujuannya untuk menguatkan pemahaman peserta didik terhadap materi pelajaran yang telah mereka peroleh di dalam kelas. Dikatakan sebagai remidial jika tujuannnya untuk memudahkan peserta didik dalam memahami materi yang telah diberikan oleh pendidik di kelas.

E-Learning berfungsi sebagai substitusi (pengganti) artinya, antara $e$ learning dengan pembelajaran di kelas kedudukan salah satunya tidak lebih tinggi dari yang lain melainkan keduanya memiliki kedudukan sama. Materi yang diperoleh peserta didik di kelas sama dengan materi yang diprogramkan melalui e-learning. Setidaknya peserta didik dapat dipilih 3 alternatif model kegiatan pembelajaran, yaitu: (1) seluruh kegiatan pembelajaran dilakukan dengan cara tatap muka (konvensional), (2) sebagian kegiatan pembelajaran dilakukan dengan cara tatap muka (konvensional) sedangkan sebagian yang lain dilakukan melalui internet, atau bahkan (3) seluruh kegiatan pembelajaran dilakukan melalui internet kapan pun dan di mana pun jika dibutuhkan karena semua bahan ajar tersimpan dalam komputer. Selain itu e-learning berfungsi sebagai substitusi (pengganti) juga memiliki kelebihankelabihan yaitu: (1) peserta didik dapat dengan mudah mengakses internet ketika mereka membutuhkan informasi tambahan yang berhubungan dengan bahan yang sedang ia pelajari (2) diskusi antara pendidik dengan peserta didik dapat dilakukan melalui internet sehingga peserta yang ingin mengikuti diskusi jumlahnya bisa sangat banyak, akhirnya dapat menambah ilmu pengetahuan dan wawasan yang lebih luas. (3) peserta didik berubah menjadi 
lebih aktif yang biasanya hanya pasif. (4) relatif lebih efesien. ${ }^{22}$

g. Model Penyelenggaraan E-Learning ${ }^{23}$

Model pembelajaran e-Learning jika dilihat dari segi penyampaiannya dapat dibagi menjadi tiga model. Menurut Rushty yang dikutip oleh Dewi Salma e-Learning memiliki tiga model yaitu adjunct model (model tambahan), mixed/blended model (model campuran/perpaduan), dan fully online model (model online penuh). Ketiga model tersebut memiliki sifat sangat lentur sehingga sulit sekali suatu model dikatakan tradisional penuh atau online penuh.

Model Adjunct; model ini adalah model tambahan atau bisa juga disebut tradisional plus. Model ini adalah model pembelajaran secara tatap muka di dalam kelas di mana media elektronik hanya digunakan sebagai penunjang pembelajaran. Model ini juga dikenal sebagai model tradisional plus karena pembelajaran masih dilakukan dengan cara tradisional namun penambahan sistem penyampaian secara online sebagai penunjang pembelajaran. Contoh seorang pendidik memberikan tugas kepada peserta didiknya untuk melakukan pencarian informasi terkait materi yang sedang dipelajari melalui internet sebagai bentuk pengayaan dari pembelajaran yang telah dilakukan di kelas.

Model Mixed/Blended; model ini merupakan pembelajaran tatap muka di kelas kemudian dipadukan dengan pembelajaran secara online. Baik pembelajaran tatap muka di kelas maupun pembelajaran secara online keduanya merupakan satu kesatuan yang utuh dan tidak dapat terpisahkan satu sama lain. Tujuan pembelajaran, mateti pembelajaran, karakteristik peserta didik serta kondisi yang ada menjadi pertimbangan dalam memilih topik pembelajaran yang akan dilaksanakan dengan cara tatap muka atau online.

${ }^{22}$ Sri Rahayu Chandrawati. 2010. Pemanfaatan E-Learning dalam Pembelajaran. Jurnal Cakrawala Kependidikan. Vol. 8. No. 2. Hlm. 175-176.

${ }^{23}$ Salma dan dkk., Mozaik Teknologi Pendidikan: E-learning, ...h.34-37. 
Model Fully Online; atau model online penuh, dalam model pembelajaran e-learning di mana proses pembelajaran dan bahan ajar yang akan disampaikan oleh guru kepada peserta didiknya dilakukan secara online. Contoh seorang pendidik memberikan bahan ajar berupa video distream melalui internet, atau pendidik membagikan link materi yang berupa teks atau gambar kepada peserta didiknya.

h. Posisi E-Learning Dalam Pembelajaran Jarak Jauh. ${ }^{24}$

Ciri utama dari pembelajaran jarak jauh adalah pendidik dan peserta didiknya dipisahan jarak maupun waktu. Sebagai konsekuensi dari keterpisahan ini adalah dengan cara menggunakan teknologi telekomunikasi sebagai sarana yang menghubungkan antara pedidik, sumber belajar, dan peserta didik. Penggunaan sarana teknologi informasi dan komunikasi secara sengaja dalam proses pembelajaran menjadi ciri khusus dari e-Learning.

E-Learning sama sekali tidak dapat terpisahkan dari pembelajaran jarak jauh. Dalam konteks pembelajaran jarak jauh, e-Learning menjadi suatu yang harus ada karena dalam pembelajaran jarak jauh keterpisahan jarak maupun waktu antara pendidik dan peserta didik tidak akan mungkin bisa dihubungkan tanpa menggunakan e-Learning. Dengan kata lain pembelajaran jarak jauh tidak akan mungkin bisa terlepas dari yang namanya e-Learning.

i. Tantangan Penerapan E-Learning

E-Learning memiliki peran dan manfaat yang besar dalam pembelajaran. E-Learning telah memberikan solusi atas masalah keterpisahan jarak dan waktu yang terjadi antara pendidik dan peserta didiknya. Namun, e-Learning sama sekali tidak memiliki masalah sendiri ketika dimanfaatkan dalam pembelajaran.

Bullen sebagaimana dikutip oleh Dani Darmawan menyebutkan permasalahan pemmanfaatan elektronik khususnya internet dalam pembelajaran. Permasalahan tersebut yaitu:

${ }^{24}$ Salma dan dkk., Mozaik Teknologi Pendidikan: E-learning, ...h 37-38. 
1) Kurangnya interaksi antara pendidik dan peserta didik, dan antar peserta didik sehingga akan mengakibatkan keterlambatan dalam terbentuknya values dalam proses pembelajaran.

2) Mendorong tumbuh kembangnya aspek bisnis/komersil semantara aspek akademik dan aspek sosial cenderung diabaikan.

3) Proses pembelajaran lebih mengarah ke pelatiahan dibanding ke pendidikan.

4) Pendidik dituntut untuk dapat mengetahui teknik pembelajaran dengan memanfaatkan ICT, setelah sebelumnya mereka hanya menguasai teknik pembelajaran konvensional.

5) Peserta didik yang memiliki motivasi belajar rendah akan cenderung mengalami kegagalan.

6) Fasilitas internet tidak menjangkau secara merata ke semua wilayah.

7) Kurangnya pengetahuan mereka terkait keterampilan berkaitan dengan internet.

8) Pelaku pendidikan kurang menguasai Bahasa komputer.

\section{j. Manfaat E-Learning}

Jika dilihat dengan lebih rinci, e-learning dapat memberi manfaat kepada kedua belah pihak, yaitu dari pihak siswa dan guru:

1) Dari pihak siswa

Dengan adanya $e$-learning fleksibilitas kegiatan belajar yang tinggi semakin berkembang. Artiya, bahan-bahan belajar yang dibutuhkan oleh siswa dapat diakses berulang-ulang kapan pun dan di mana pun. Kegiatan berkomunikasi antara siswa dengan gurunya dapat dilakukan kapan saja. Kondisi yang demikian ini, membuat siswa menjadi lebih mantap dalam mengerjakan tugas terhadap materi pembelajarannya. Kegiatan e-learning dapat memberikan banyak manfaat kepada siswa ketika fasilitas infrastruktur ini telah mampu menjangkau ke daerah kecamatan hingga pedesaan, tidak hanya berkutat di daerah perkotaan saja, diantara manfaatmanfaatnya yaitu: 
(a) Siswa dari daerah miskin yang belajar di sekolah-sekolah kecil bisa mendapatkan beberapa mata pelajaran yang belum pernah mereka temui sebelumnya karena sekolahnya tidak mampu memberikan mata pelajaran tersebut kepadanya.

(b) Siswa dapat ikut dalam program pendidikan keluarga dari rumah mereka masing-masing untuk mempelajari bahasa asing dan ketrampilan dalam bidang komputer dimana orangtua mereka tidak mampu mengajarkan materi pembelajaran tersebut kepada mereka.

(c) E-learning menjadi solusi bagi siswa yang mengalami phobia dengan sekolah, atau bagi siswa yang sedang sakit yang sedang dirawat di rumah sakit maupun dirumah mereka, siswa-siswa yang putus sekolah tetapi mereka mempunyai keinginan untuk melanjutkan program pendidikannya, siswa yang dikeluarkan oleh sekolah, maupun siswa-siswa yang tinggal di daerah atau bahkan mereka yang tinggal di luar negeri.

(d) Siswa bisa mendapatkan pendidikan meskipun sekolah konvensional tidak dapat menampung mereka.

2) Dari pihak guru

Guru bisa mendapatkan berbagai manfaat dari adanya kegiatan $e$ learning beberapa manfaat tersebut diantaranya yaitu:

(a) Guru akan lebih mudah dalam melaksanakan tanggung jawabnya yaitu melakukan pembaharuan bahan-bahan belajar yang akan disampaikan kepada peserta didiknya sebagai bentuk penyesuaian atas tuntutan perkembangan keilmuan yang sedang berkembang saat itu,

(b) Waktu luang yang dimiliki oleh guru relatif lebih banyak sehingga ia dapat melakukan pengembangan diri atau melakukan berbagai penelitian yang berguna untuk meningkatkan wawasannya,

(c) Guru dapat mengontrol kegiatan belajar yang dilakukan oleh siswanya. Bahkan kapan siswanya mulai belajar juga dapat diketahui oleh guru, topik-topik apa saja yang sedang dipelajari oleh siswanya, 
durasi topik tersebut dipelajari oleh siswanya, serta topik tersebut dipelajari ulang oleh siswanya berapa kali,

(d) Guru dapat memonitor apakah semua siswanya telah mengerjakan seluruh soal latihan yang ia berikan, dan

(e) Guru dapat memeriksa semua jawaban dari latihan yang telah ia berikan kepada siswa dan memberikan hasilnya kepada siswa. ${ }^{25}$

k. Kelebihan dan Kekurangan Pembelajaran E-Learning

1) Kelebihan pembelajaran e-learning

(a) Adanya fasilitas e-moderating dimana fasilitas tersebut dapat dimanfaatkan oleh guru dan siswa untuk berkomunikasi secara reguler dengan mudah, kapan pun dan di mana pun kegiatan tersebut dilakukan tanpa adanya batasan jarak, tempat dan waktu,

(b) Melalui internet Guru dan siswa dapat menggunakan materi ajar yang telah terstruktur dan terjadwal dalam waktu yang bersamaan, dimana antara guru dan siswa dapat menilai seberapa jauh materi ajar yang telah dipelajari,

(c) Materi ajar yang telah diterima oleh siswa dapat mereka ulang atau meraka review kapan pun dan di mana pun mereka inginkan, karena materi ajar tersebut telah tersimpan di komputer,

(d) Siswa yang membutuhkan informasi mengenai materi ajar yang akan ia pelajari dapat mengakses materi ajar tersebut melalui internet,

(e) Internet memungkinkan guru dan siswa dapat melakukan interaksi atau diskusi dalam jumlah peserta yang banyak, sehingga ilmu pengetahuan dan wawasan yang dimiliki akan semakin bertambah luas,

(f) Siswa yang awalnya pasif akan berubah menjadi lebih aktif dalam pembelajaran,

(g) Lebih efisien dalam waktu bilamana kondisi siswa jauh dari tempat

${ }^{25}$ Ratna Tiharita Setiawardhani. 2013. Pembelajaran Eloktronik (E-Learning) dan Internet dalam Rangka Mengoptimalkan Kreativitas Belajar Siswa. Edunomik, Jurnal Ilmiah Pendudukan Ekonomi. Vol. 1. No. 2. Hlm. 86-87. 
belajarnya atau sekolah konvesional.

2) Kekurangan pembelajaran e-learning

(a) Terbentuknya values akan terjadi keterlambatan di dalam proses kegiatan belajar mengajar (KBM) sebagai akibat dari kurangnya interaksi antara guru dan siswa atau antara siswa dengan siswa sendiri,

(b) Mendorong tumbuh kembangnya aspek komersil atau bisnis sedangkan aspek akademik atau aspek sosial akan cenderung diabaikan,

(c) Pada proses kegiatan belajar mengajar (KBM) lebih cenderung ke arah pelatihan daripada pendidikan,

(d) Peran guru mengalami perubahan, yang awalnya hanya teknik pembelajaran konvensional yang dikuasai, kini mereka dituntut untuk menguasai teknik pembelajaran dengan pemanfaatan sarana teknologi informasi dan komunikasi,

(e) Siswa akan cenderung mengalami kegagalan dalam belajar karena memiliki motivasi belajar yang rendah,

(f) Tidak semua tempat ada fasilitas internet,

(g) Kurangnya tenaga yang mengetahui dan terampil dalam penguasaan internet dan kurangnya penguasaan bahasa komputer atau bahasa pemrograman. ${ }^{26}$

\section{Metode Penelitian}

Pendekatan yang dipakai dalam penelitian ini adalah pendekatan kualitatif. Arikunto (2010:16) mendefinisikan "Metode kualitatif sebagai suatu prosedur penelitian yang menghasilkan data deskriptif dalam bentuk kata-kata tertulis maupun lisan dari orang-orang dan perilaku yang dapat diamati”. Subjek penelitian ini adalah 5 orang guru tematik dari kelas I sampai V dan seseorang Wakil Kepala Kesiswaan di Madrasah Ibtidaiyah Nurul Ummah

26 Nuke L. Chusna. 2019. Pembelajaran E-Learning. Prosiding Seminar Nasional Pendidikan KALUNI. Vol. 2. Hlm. 116. 
(MINU) Kotagede Yogyakarta, dengan teknik pengumpulan data melalui observasi dan wawancara.

\section{Hasil dan Pembahasan}

\section{Pembelajaran Tematik Jarak Jauh Selama Masa Pandemi Covid-19 di Madrasah Ibtidaiyah Nurul Ummah (MINU) Kotagede Yogyakarta}

Madrasah Ibtidaiyah Nurul Ummah (MINU) merupakan sekolah yang memadukan kurikulum pesantren, kemenag, dan kemendikbud. MINU memiliki program unggulan yakni Tahsin-Tahfidz. MINU menerapkan Full day school dengan 6 hari sekolah. ${ }^{27}$ Surat Edaran Mendikbud Nomor 4 tahun 2020 merupakan titik awal MINU menerapakan pembelajaran jarak jauh setelah sebelumya selalu menggunakan pembelajaran secara tatap muka di kelas. Hal ini menjadi salah satu alasan kenapa penulis memilih MINU untuk menjadi objek. Dari teori yang telah dipaparkan, bahwasanya pembelajaran jarak jauh dan e-learning memiliki beberapa komponen, fungsi, serta tantangannya. Adapun penjelasan terkait dengan pelaksanaan pembelajaran tematik jarak jauh di MINU akan dijelaskan lebih lanjut.

\section{Pelaksanaan Pembelajaran Tematik Jarak Jauh Selama Masa} Pandemi Covid-19 di MI Nurul Ummah

Pelaksanaan pembelajaran jarak jauh di MINU termasuk di dalamnya pembelajaran tematik dilaksanakan setelah dikeluarkannya Surat Edaran Mendikbud Nomor 4 tahun 2020, tepatnya pada tanggal 16 Maret 2020. Setelah sebelumnya diadakan rapat terbatas mengenai pembelajaran jarak jauh.

Dari wawancara dengan Wakil Kepala Kesiswaan MINU bernama pak Yudha, bahwa ${ }^{28}$ :

\footnotetext{
${ }^{27}$ Dokumen profil MINU 2019
}

${ }^{28}$ Wawancara dengan pak Yudha, Wakil Kepala Kesiswaan MINU tanggal 21Maret 2020 jam 14.00 
"Setelah rapat terbatas dengan kepala sekolah dan guru-guru akhirnya kami putuskan pembelajaran jarak jauh dilaksanakan mulai tanggal 16 Maret 2020. Pembelajaran jarak jauh ini dilakukan dengan menggunakan aplikasi WhatsApp. ”

Dalam perjalannya pembelajaran jarak jauh tidak hanya menggunakan aplikasi WhatsApps, namun juga menggunakan sarana lain seperti Googleform dan Google Classroom. Wawanacara dengan bu Maimunah guru Tematik kelas V MINU menjelaskan ${ }^{29}$ :

“Sebelumnya kami menggunakan aplikasi WhatsApps dalam pembelajaran jarak-jauh, namun setelah kami evaluasi sering kali materi yang kami bagikan ke siswa sering tertimbun oleh pesan-pesan lain. Akhirnya, kami berembug denggan beberapa guru untuk menggunakan Google Classroom. Kami guru tematik mengundang guru mapel di dalamnya. Materi kami sampaikan ke siswa melalui Google Classroom ini, biasanya berupa link video. Untuk pengerjaan tugas kami menggunakan Googleform.”

Dalam wawancara diatas komponen-komponen pembelajaran jarak jauh telah ada di MINU. MINU adalah lembaga yeng menyelenggarakan pembelajaran jarak jauh. Pendidik dan peserta didik saling terpisah satu sama lain. Menggunakan telekomunikasi interaktif di sini berupa aplikasi WhatsApp dan Google Classroom. Pendidik dan peserta didik saling berbagi data melalui link yang dibagikan melalui Google Classroom.

Pembelajaran jarak jauh di MINU memiliki fungsi sebagai pengganti pembelajaran di kelas yang belum mungkin dilaksanakan dalam keadaan pandemi covid-19 ini. Semua materi yang disampaikan dalam pembelajaran jarak jauh melalui internet adalah materi yang sama ketika pembelajaran tersebut dilaksanakan dengan cara konvensional atau tatap muka secara langsung. jam 14.30

${ }^{29}$ Wawancara dengan bu Maimunah, guru Tematik kelas V MINU tanggal 26Maret 2020 
Model pembelajaran jarak jauh yang dipakai di MINU pada masa pandemi covid-19 ini berupa Fully Online (Model online penuh). Materi dan bahan ajar yang disampaikan pendidik kepada peserta didiknya dilakukan secara online. Dimana pendidik di MINU memberikan bahan ajar berupa link materi atau link video melalui internet yang dalam hal ini melalui aplikasi WhatsApps dan Google Classroom.

\section{Kendala Guru dalam Pembelajaran Tematik Jarak Jauh Selama} Masa Pandemi Covid-19 di Madrasah Ibtidaiyah Nurul Ummah (MINU) Kotagede Yogyakarta

Pembelajaran tematik jarak jauh di MINU memiliki beberapa kendala khususnya bagi guru itu sendiri. Dalam wawancara penulis terhadap guru tematik di MINU, sebagian besar dari mereka belum pernah mengikuti pelatiahan pembelajaran jarak jauh. Bu Susi guru tematik kelas II dalam wawancaranya mengatakan: ${ }^{30}$

“Kami cenderung kaget dalam melaksanakan pembelajaran jarak jauh karena hal ini terlalu mendadak. Sementara itu, kami belum pernah mendapatkan pelatihan mengenai ini sebelumnya”.

Sebagian besar guru tematik MINU pulang ke daerahnya masingmasing sehingga dalam melaksanakan pembelajaran jarak jauh sering kali terjadi gangguan jaringan internet. Hal ini diungapkan bu Aini guru Tematik kelas III dalam wawancaranya dengan penulis. ${ }^{31}$

“Sering kali koneksi internet kurang lancar, sehingga ketika saya menggunakan Google Classroom dalam pembelajaran tematik jarak jauh sering terganggu.”

Menurut Speedtest.net kecepatan internet Indonesia berada di posisi 113 dari 139 negara, di bawah negara-negara ASEAN lain seperti

\footnotetext{
${ }^{30}$ Wawancara dengan bu Susi, guru Tematik kelas II MINU tanggal 24Maret 2020 jam 
singspore (13), Vietnam (49) Thailand (64), Laos (90), Malaysia (98). ${ }^{32}$ Jadi wajar jika kendala koneksi internet kurang lancar terjadi dalam pembelajaran tematik jarak jauh ini.

Selain masalah jaringan internet, masalah biaya juga menjadi masalah lain dalam pembelajaran jarak jauh karena dalam pelaksanaannya membutuhkan kuota internet yang cukup banyak di mana harga kuota internet cenderung mahal. Bu Ririn guru tematik kelas I mengeluhkannya ketika diwawancarai oleh penulis. ${ }^{33}$

"Sejak pembelajaran jarak jauh saya lumayan boros kuota pak, selama pembelajaran jarak jauh ini sekolah belum memberi anggaran untuk beli kuota kepada kami. Seharusnya ada uang kuota untuk kami.”

Pembelajaran tematik jarak jauh di MINU sebagian besar menggunakan gawai karena setiap guru dan wali murid memilikinya. Wali murid memiliki peran penting dalam pembelajaran jarak jauh karena anak masih perlu pendamping dalam menggunakan gawai. Sayangnya tidak semua wali murid memiliki ketrampilan yang baik dalam menggunakan gawai sebagai sarana untuk pembelajaran jarak jauh. Saat penulis melakukan observasi, penulis menjumpai ada salah satu wali murid yang mengunjungi sekolah untuk meminta bantuan kepada salah satu guru agar diberi tahu bagaimana mengoperasikan aplikasi Google Classroom. ${ }^{34}$

Kesibukan wali murid dengan berbagai pekerjaannya juga menjadikan mereka tidak bisa sepenuhnya mendampingi anaknya untuk melaksanakan pembelajaran jarak jauh dengan baik. Sehingga sering kali tugas yang diberikan pendidik kepada peserta didiknya tidak dapat diselesaikan. Tugas-tugas dari peserta didik yang sering tidak dikirim membuat pendidik kesulitan dalam pelakukan evaluasi

32“'Speedtest Global Index-Monthly comparasion of internet speeds from around the

${ }^{33}$ Wawancara dengan bu Ririn, guru Tematik kelas I MINU tanggal 3Mei 2020 jam 15.00

${ }^{34}$ Pengamatan langsung saat observasi 
pembelajarannya. $^{35}$

Pembelajaran jarak jauh yang dilaksanakan setiap hari juga membuat peserta didik bosan. Hal ini menjadi kendala bagi guru dalam melaksanakan pembelajaran jarak lauh. Anak-anak sudah mulai bosan mengikuti pembelajaran jarak jauh sejak minggu keempat. Hal ini membuat materi-materi yang diberikan oleh pendidik sering kali tidak dipelajari oleh peserta didik. ${ }^{36}$

\section{Kesimpulan}

Pembelajaran jarak jauh memiliki komponen, fungsi, model dan berbagai tantangan dalam penerapannya. Tidak terkecuali pada pembelajaran tematik jarak jauh di Madrasah Ibtidaiyah Nurul Ummah (MINU) Kotagede Yogyakarta. Pembelajaran tematik jarak jauh di MINU berfungsi sebagai pengganti pembelajaran konvensional yang selama ini dilaksanakan. Model yang dipakai berupa Fully Online (model online penuh). Dalam pelaksanaannya, guru mengalami berbagai kendala baik kendala di internal pendidik sendiri maupun kendala di luar pendidik. Kendala di internal pendidik yaitu ketidak siapan pendidik di awal penerapan pembelajaran tematik jarak jauh, karena sebagian besar belum pernah mengikuti pelatihan pembelajaran jarak jauh. Sementara kendala yang di luar pendidik yaitu terkait dengan koneksi internet yang kurang lancar, pendampingan wali murid yang kurang optimal, dan peserta didik yang mulai jenuh dengan pembelajaran jarak jauh. Pihak terkait sebaiknya segera memberikan pelatihan pembelajaran jarak jauh kepada guru-guru sehingga pembelajaran jarak jauh dapat berjalan dengan efektif.

\footnotetext{
${ }^{35}$ Wawancara dengan bu Eka, guru Tematik kelas IV MINU tanggal 3Mei 2020 jam 15.00

${ }^{36}$ Wawancara dengan pak Riski, guru tematik kelas 2 MINU tanggal 4Mei 2020 jam 1.00
} 


\section{DAFTAR PUSTAKA}

Covid19.Go.Id. “Covid19.Go.Id,” 2020.

Darmawan, Deni. Pengembangan E-Learning Teori Dan Desain. Bandung: Pt Remaja Rosdakarya, 2014.

Dewi, Wahyu Aji Fatma. "Dampak Covid-19 Terhadap Implementasi Pembelajaran Daring Di Sekolah Dasar.” Edukatif: Jurnal Ilmu Pendidikan 2, No. 1 (April 29, 2020): 55-61. Https://Doi.Org/10.31004/Edukatif.V2i1.89.

Karwati, Euis. "Pengaruh Pembelajaran Elektronik (E-Learning) Terhadap Mutu Belajar Mahasiswa.” Jurnal Penelitian Komunikasi 17 (2014): 41-54.

Kumparan. "Prediksi Akhir Pandemi Corona Di Indonesia Mundur Lagi Jadi Oktober,” 2020.

Osterholm, Michael T., Dan Kristine A. Moore. "Covid-19: The Cidrap Viewpoint.” Minnesota, 2020.

Prastowo, Andi. Analisis Pemmbelajaran Tematik Terpadu. Jakarta: Prenadamedia Group, 2019.

Salma, Dewi, Dan Dkk. Mozaik Teknologi Pendidikan: E-Learning. Jakarta: Kencana, 2013.

Speedtest.Net. "Speedtest Global Index-Monthly Comparasion Of Internet Speeds From Around The World,” 2020.

Sulistyo Hanum, Numiek. "Keefektifan E-Learning Sebagai Media Pembelajaran (Studi Evaluasi Model Pembelajaran E-Learning Smk Telkom Sandhy Putra Purwokerto).” Jurnal Pendidikan Vokasi 3 (2013): 90-102.

Pusvyta Sari. 2015. Memotivasi Belajar Dengan Menggunakan E-Learning. Jurnal Ummul Qura. Vol. 6. No. 2.

Mohammad Yazdi. 2012. E-Learning Sebagai Media Pembelajaran Interaktif Berbasis Teknologi Informasi. Jurnal Ilmiah Foristek. Vol. 2. No. 1.

Intan Mutia, Leonard. 2013. Kajian Penerapan E-Learning Dalam Proses Pembelajaran Di Perguruan Tinggi. Faktor Exacta. Vol. 6. No. 4.

Rifa'i, Ilyas, Ferli Septi Irwansyah, Mar'atus Sholihah, And Astri Yuliawati. "Dampak Dan Pencegahan Wabah Covid-19: Perspektif Sains Dan 
Islam.” Jurnal Lembaga Penelitian Dan Pengabdian Masyarakat (Lp2m), April 29, 2020. Http://Digilib.Uinsgd.Ac.Id/30549/.

Sri Rahayu Chandrawati. 2010. Pemanfaatan E-Learning Dalam Pembelajaran. Jurnal Cakrawala Kependidikan. Vol. 8. No. 2.

Syah, Rizqon H. "Dampak Covid-19 Pada Pendidikan Di Indonesia: Sekolah, Keterampilan, Dan Proses Pembelajaran.” Salam: Jurnal Sosial Dan Budaya Syar-I 7, No. 5 (April 14, 2020). Https://Doi.Org/10.15408/Sjsbs.V7i5.15314.

Syapitri, Henny, Laura Mariati Siregar, And Frida Liharis Saragih. "Pencegahan Penularan Covid-19 Melalui Sosialisasi Dan Pembagian Masker Di Pasar Pringgan Medan.” Jurnal Kreativitas Pengabdian Kepada Masyarakat $(P k m) \quad 3, \quad$ No. 2 (October 6, 2020): 422-29. Https://Doi.Org/10.33024/Jkpm.V3i2.2902.

Ratna Tiharita Setiawardhani. 2013. Pembelajaran Eloktronik (E-Learning) Dan Internet Dalam Rangka Mengoptimalkan Kreativitas Belajar Siswa. Edunomik, Jurnal Ilmiah Pendudukan Ekonomi. Vol. 1. No. 2.

Nuke L. Chusna. 2019. Pembelajaran E-Learning. Prosiding Seminar Nasional Pendidikan Kaluni. Vol. 2.

Uu Nomor 20 Tahun 2003 Pasal 1ayat 15.

Who. “Emergencies Diseases Novel Coronavirus-2019,” 2020.

Yunitasari, Ria, And Umi Hanifah. "Pengaruh Pembelajaran Daring Terhadap Minat Belajar Siswa Pada Masa Covid 19.” Edukatif: Jurnal Ilmu Pendidikan 2, No. 3 (September 22, 2020): 232-43. Https://Doi.Org/10.31004/Edukatif.V2i3.142. 
